\title{
Effects of Coptis chinensis Extracts on Matrix Metalloproteinase-1 Suppression through JNK/AP-1 Axis in Human Dermal Fibroblasts
}

\author{
Ji Yea Kim ${ }^{1,2}$, Seunghee Bae ${ }^{1}$, Jinhyuk Jung ${ }^{2}$, Sungkwan $\mathrm{An}^{1}$, In Sook $\mathrm{An}^{2}$, Young-Sam $\mathrm{Kim}^{3 *}$ \\ ${ }^{1}$ Research Institute for Molecular-Targeted Drugs, Department of Cosmetics Engineering, Konkuk University, Seoul, Korea \\ ${ }^{2}$ Korea Institute of Dermatological Sciences, Seoul, Korea \\ ${ }^{3}$ Department of Image Industry, Graduate School of Engineering, Konkuk University, Seoul, Korea
}

\author{
*Corresponding author: Young-Sam Kim, \\ Department of Image Industry, Graduate \\ School of Engineering, Konkuk University, 120 \\ Neungdong-ro, Gwangjin-gu, Seoul 05029, \\ Korea \\ Tel.: +82 24503595 \\ Email: gracehelen@konkuk.ac.kr
}

Received July 5, 2018

Revised July 24, 2018

Accepted July 31, 2018

Published September 30, 2018

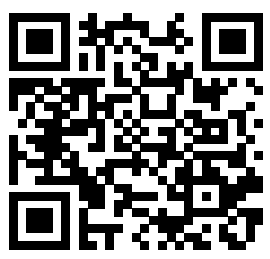

\begin{abstract}
Purpose: In this study, we investigate the effect of Coptis chinensis extract (CCE) on matrix metalloprotease 1 (MMP1) expression in dermal fibroblasts. Methods: Human dermal fibroblasts (HDFs) were used to assess the effect of CCE on oxidative stress-induced MMP1 expression. A water-soluble tetrazolium salt (WST-1) assay was conducted to determine the cytotoxicity of CCE in HDFs. To investigate whether CCE has a protective effect on oxidative stress-induced MMP1 downregulation, HDFs were pretreated with CCE $(2.5$ and $5 \mu \mathrm{g} / \mathrm{mL})$ for $9 \mathrm{~h}$, and then with $200 \mu \mathrm{M} \mathrm{H}_{2} \mathrm{O}_{2}$ for $3 \mathrm{~h}$. Total RNAs were collected and the level of MMP1 expression was determined using quantitative real-time polymerase chain reaction (qRT-PCR) assay with its specific primers. Also, luciferase reporter gene assay for activator protein-1 (AP-1) activity was performed with AP-1 luciferase reporter gene constructs transfected into HDFs. Furthermore, c-Jun N-terminal kinase (JNK) and p-JNK protein levels were detected by western blot analysis. Results: Lower concentration of CCE $(<5 \mu \mathrm{g} / \mathrm{mL})$ showed little cytotoxicity in HDFs. Pre-treatment of the cells with CCE significantly inhibited $\mathrm{H}_{2} \mathrm{O}_{2}$-induced MMP1 downregulation. Further experiments revealed that CCE-mediated MMP1 downregulated was mediated via suppression of AP-1 transcriptional activity. Moreover, western blot analysis revealed that CCE inhibited the phosphorylation and activation of JNK, which is known to enhancing AP-1 activation. Therefore, these results indicate that CCE regulates MMP1 expression via JNK/AP-1 signaling pathway in HDFs. Conclusion: These results in this paper show that CCE has a protective effect on oxidative stress-induced MMP1 expression in HDFS and may uses as a possible reagent on anti-aging cosmetics.
\end{abstract}

Keywords: Coptis chinensis, Dermal fibroblasts, Matrix metalloproteinase, Oxidative stress, JNK/AP-1 signaling pathway

\section{Introduction}

인체 피부 노화는 내인적 및 외인적 요인에 의해 피부의 구조 적 및 생리학적 기능이 서서히 변하는 것을 말한다(Friedman, 2005). 내인적 요인에 의한 노화는 시간의 흐름에 따라 자연적 으로 나타나는 생리적 기능의 변화로, 나이에 따른 노화, 체내 신진대사의 저하 및 호르몬 불균형 등 주로 유전적인 요인에 의 해 결정된다(Bergfeld, 1997). 이와 달리, 외인적 요인에 의한 피부 노화는 과도한 햇빛, 자외선, 미세먼지, 흡연, 식습관, 수
면 등 매우 다양한 요인들에 의해 결정된다(Bergfeld, 1997). 이 런 두 가지 노화 과정에서 활성산소(reactive oxygen species, $\mathrm{ROS}$ )가 발생되는데, 이는 노화의 주 원인으로 인체의 DNA를 손 상시켜 단백질 발현을 방해하고 세포와 조직을 손상시켜 피부 노 화를 촉진시킨다(Sies \& de Groot, 1992).

인체 피부는 표피와 진피로 구분되며, 진피는 콜라겐 (collagen), 엘라스틴 섬유(elastin), 히알루론산 등을 포함하고 있는 세포외기질(extracellular matrix, $\mathrm{ECM}$ )로 구성되어 있 다. 콜라겐은 세포외기질의 주요 구성성분으로 이 중 제 1 형 콜 
라겐(collagen types I, COL1A1)은 조직의 구조와 기능을 유지 하는 핵심 단백질로써 역할을 한다(Abergel et al., 1987; Mays et al., 1988). 따라서 내인성 노화와 외인성 노화에 의한 제 1 형 콜라겐의 변형은 진피층의 구조 변형을 초래해 피부의 탄력이 감소되고 주름이 생성되는 노화현상이 나타난다(Lavker, 1979; Rinnerthaler et al., 2015; Smith et al., 1962). 이는 내인 성 노화와 외인성 노화에 의해 생성된 활성산소가 제 1 형 콜라 겐분해효소인 $M M P 1$ 의 발현을 증가시키기 때문이며(BirkedalHansen et al., 1993; Ha \& You, 2016; Kim, 2016), 활성 산소에 의한 $M M P 1$ 발현 증가는 이미 여러 연구에서 보고된 바 있다. 노화가 진행될 때 활성산소는 JNK을 활성화시키고 transcription factor $\mathrm{AP}-1$ complex인 c-FOS와 c-JUN의 활 성을 유도하여 $M M P 1$ 의 발현을 증가시키기 때문에 제 1 형 콜 라겐의 분해가 일어나 결국 진피층이 퇴화되어 주름이 생성된 다(Fisher et al., 1996; Lavker et al., 1995). 따라서 JNK/ $\mathrm{AP}-1 / \mathrm{MMP} 1$ 의 신호전달을 차단하여 노화를 억제할 수 있는 물 질들의 연구개발이 최근까지 꾸준히 이어지고 있다(Lam et al., 2005; Lu et al., 2016; Newberry et al.,1997).

Coptis chinensis은 중국 중부지방이 원산지로 자생 또는 약초 로 재배되고 있으며, 중국의 전통 약재로써 사용되어 왔다(Lee et al., 2006). Coptis chinensis는 베르베린(berberine)와 같은 항 산화제를 포함하고 이는 강력한 항균, 항염증, 항암, 지혈, 혈압 강하 등의 약리작용을 가진 것으로 알려져 있다(Hattori et al., 1992; Lee et al., 2003). 최근 연구에 의하면 Coptis chinensis 추출물은 간암세포에서 항산화 작용을 통해 활성산소 생성을 막 아 간 세포 손상에 대한 보호 효과가 있다고 알려졌다(Ma et al., 2018). 뿐만 아니라 Coptis chinensis 추출물은 흑색종 암세포 에서 melanogenesis associated transcription factor (MITF) 을 조절하여 멜라닌 생성과정을 조절하는 미백 효과에 대한 연 구도 보고 되어있다(Lee et al., 2017). 이렇게 꾸준히 Coptis chinensis에 대한 연구가 진행됨에도 불구하고 주름개선 및 항 노화 효과에 대해서 알려진 바가 적다. 따라서 본 연구에서는 Coptis chinensis 추출물의 MMP1 발현 조절에 대한 분자세포학 적 기전을 밝히고 나아가 새로운 항노화 화장품 원료로써의 가능 성을 밝히고자 한다.

\section{Methods}

Table 1. Sequences of the primers for qRT-PCR

\begin{tabular}{lll}
\hline Gene & \multicolumn{1}{c}{ Forward primers } & \multicolumn{1}{c}{ Reverse primers } \\
$M M P 1$ & 5'-TCTGACGTTGATCCCAGAGAGCAG-3' & 5'-CAGGGTGACACCAGTGACTGCAC-3' \\
$\beta$-ACTIN & 5'-GGATTCCTATGTGGGCGACGA-3' & 5'-CGCTCGGTGAGGATCTTCATG-3' \\
\hline
\end{tabular}

qRT-PCR, quantitative real-time polymerase chain reaction; MMP1, matrix metalloprotease 1.

\section{1. 인간진피섬유아세포 배양}

인간진피섬유아세포(human dermal fibroblasts, HDFs)는 Lonza사(Basel, Switzerland)에서 구입하였으며, Dulbecco's modified Eagle's medium (DMEM, L0103-500; Biowest, France)에 10\% fetal bovine serum (FBS, S1480; Biowest)이 포함된 배지를 사용하여 $37^{\circ} \mathrm{C}, 5 \% \mathrm{CO}_{2}$ 세포배양기에서 배양하 였다.

\section{Coptis chinensis 추출물의 제조}

건조된 Coptis chinensis는 분쇄기(SMX-5800LM; Shinil, Korea)를 이용하여 분말화한 후, $70 \%$ ethanol을 첨가하여, $60{ }^{\circ} \mathrm{C}$ 에서 $30 \mathrm{~min}$ 동안 가열하여 Coptis chinensis 추출물 을 제조하였다. 해당 추출물은 여과지(Whatman No.2; GE Healthcare Life Sciences, USA)를 통해 1차 분리하고, 여과된 추출물은 감압농축 후 동결 건조 하였다. 해당 동결 건조된 추출 물은 dimethyl sulfoxide (DMSO, Sigma-Aldrich, USA)에 녹 여 실험에 사용하였다.

\section{3. 세포독성 측정}

Coptis chinensis 추출물의 세포독성은 WST-1 assay (EZcytox cell viability kit; Itshio, Korea)을 이용하여 확인하였 다. HDFs를 $4 \times 10^{3}$ cells/well씩 96-well plate에 분주하여 $24 \mathrm{~h}$ 동안 배양한 후, Coptis chinensis 추출물을 $0.5,1,2.5$, $5,10 \mu \mathrm{g} / \mathrm{mL}$ 씩 처리하였다. $24 \mathrm{~h}$ 처리 후, WST-1 assay 용 액을 배지에 처리하여 세포배양기에서 $1 \mathrm{~h}$ 반응시켰다. iMark microplate reader (Bio-Rad, USA)을 이용하여 $450 \mathrm{~nm}$ 의 파 장에서 흡광도를 측정하였다. Reference 흡광도는 $650 \mathrm{~nm}$ 의 파 장에서 측정한 뒤 해당 결과값을 보정하였다.

\section{MMP1 mRNA의 발현 변화의 측정}

Coptis chinensis 추출물에 의한 $M M P 1 \mathrm{mRNA}$ 발현 변화 는 $\mathrm{qRT}-\mathrm{PCR}$ 를 이용하여 분석하였다. 먼저, $\mathrm{HDFs}$ 를 $60 \mathrm{~mm}$ culture dish에 $2 \times 10^{5}$ cells씩 분주하여 $24 \mathrm{~h}$ 동안 배양한 후, 2.5 및 $5 \mu \mathrm{g} / \mathrm{mL}$ 의 Coptis chinensis 추출물을 $9 \mathrm{~h}$ 전처리 하 였다. 이 후, 배지를 제거한 후, $200 \mu \mathrm{M} \mathrm{H}_{2} \mathrm{O}_{2}$ 를 $3 \mathrm{~h}$ 처리하였 다. 세포를 수확한 후, TRIzol reagent (Life Technologies, $\mathrm{USA})$ 을 이용하여 total RNAs 추출하고, MaestroNano ${ }^{\circledR}$ microvolume spectrophotometer (Maestrogen, USA) 
을 이용하여 A260/A280 파장에서 해당 $\mathrm{RNA}$ 의 농도와 순도 를 측정하였다. 이 후 추출된 total RNA는 $\mathrm{M}-\mathrm{MLV}$ reverse transcriptase (Life Technologies, USA)를 이용하여 cDNA 로 합성하였다. 합성된 $\mathrm{cDNA}$ 는 해당 유전자의 primer와 SYBR Green PCR Master Mix (Thermo Fisher Scientific, USA) 를 혼합하고 StepOnePlus Real-Time PCR System (Thermo Fisher Scientific) 기기를 이용하여 qRT-PCR을 수행하였 다. $\beta-A C T I N$ mRNA는 loading control로써 사용하여 $M M P 1$ $\mathrm{mRNA}$ 발현 값을 보정하였다. $\mathrm{qRT}-\mathrm{PCR}$ 에 사용된 primer의 정 보는 Table 1 과 같다.

\section{5. $\mathrm{AP}-1$ 활성 측정}

Coptis chinensis의 추출물에 의한 AP-1 활성은 luciferase assay을 통해 측정되었다. 본 실험을 위해 12-O-tetradecanoylphorbol13-acetate (TPA) responsive element (TRE)라는 AP-1 binding site region을 지닌 promoter가 삽입된 luciferase reporter vector (pGL-TRE; Promega, USA)와 normalization plasmid (pCMV- $\beta$-gal; Promega)을 사용하였다. 먼저, HDFs 를 $2 \times 10^{5}$ cells씩 $60 \mathrm{~mm}$ dish에 분주한 후 $24 \mathrm{~h}$ 동안 배양하 였다. 그 다음 Lipofectamine 3000 (Invitrogen, USA)을 이 용하여 $1 \mu \mathrm{g}$ 의 $\mathrm{pGL}-\mathrm{TRE}$ 과 $0.2 \mu \mathrm{g}$ 의 $\mathrm{pCMV}-\beta$-gal을 동시 에 transfection한 후 $24 \mathrm{~h}$ 추가 배양하였다. Transfection된 세포에 $\mathrm{H}_{2} \mathrm{O}_{2}(200 \mu \mathrm{M})$ 과 Coptis chinensis 추출물을 2.5 및 5 $\mu \mathrm{g} / \mathrm{mL}$ 씩 처리하여 배양한 뒤 passive lysis buffer (Promega) 을 이용해 용해시킨 후 원심분리 하여 각 세포들의 상층액을 얻 었다. 이 후 luciferase 활성을 확인하기 위해 각 세포의 상층액 은 luciferase reagent (Promega)와 반응시켜 Luminometer (VeritasTM; USA) 기기를 이용해 luciferase의 발광 정도를 측 정하였다. 각 세포의 Transfection 효율을 보정하기 위해 같은 상층액을 0-nitrophenyl- $\beta-\mathrm{D}$-galactopyranoside (ONPG)와 반응시켜 $\beta$-galactosidase의 활성을 측정하였고, 측정된 값을 이용하여 luciferase 결과 값을 보정하였다.

\section{JNK 단백질의 활성 측정}

Coptis chinensis 추출물에 의한 $M M P 1 \mathrm{mRNA}$ 의 발현 감소 가 $\mathrm{JNK}$ 단백질 활성과 관련되어 있는지 확인하기 위해 인산화된 $\mathrm{JNK}$ 와 JNK 단백질의 발현을 Western blot을 통해 확인하였다. 먼저, $\mathrm{HDFs}$ 를 $60 \mathrm{~mm}$ culture dish에 $2 \times 10^{5}$ cells씩 분주하 여 $24 \mathrm{~h}$ 동안 배양한 후, 2.5 및 $5 \mu \mathrm{g} / \mathrm{mL}$ 의 Coptis chinensis 추출물을 $9 \mathrm{~h}$ 전처리 하였다. 이 후, 배지를 제거한 후, $200 \mu \mathrm{M}$ $\mathrm{H}_{2} \mathrm{O}_{2}$ 를 $3 \mathrm{~h}$ 처리하였다. 세포는 RIPA lysis buffer $(150 \mathrm{mM}$ $\mathrm{NaCl}$ (Biopure, USA), $50 \mathrm{mM}$ pH 7.5 Tris-Cl (Biopure), 1\% NP-40 (Biopure), 0.5\% sodium deoxycholate (Biopure), $0.1 \%$ sodium dodecyl sulfate (Biopure), protease inhibitor

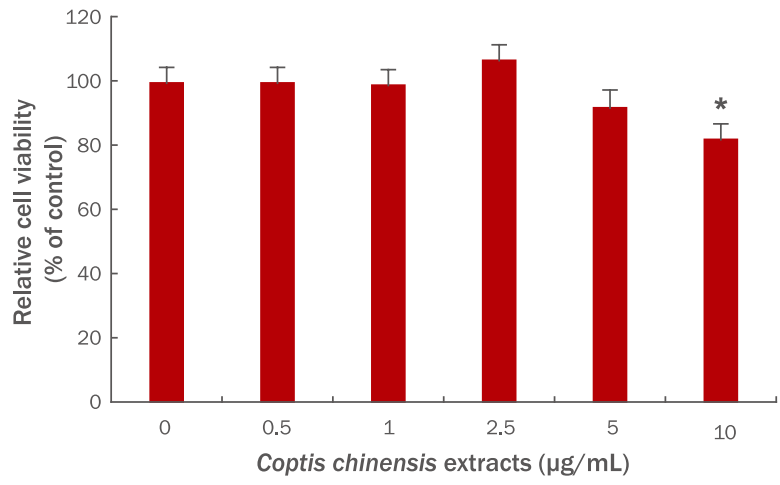

Figure 1. Cytotoxicity of Coptis chinensis extracts in HDFs. HDFs were treated with $0.5-10 \mu \mathrm{g} / \mathrm{mL}$ of Coptis chinensis extracts. After $24 \mathrm{~h}$ of incubation, a WST-1 reagent was added in each well and incubated for $1 \mathrm{~h}$. The absorbance was measured using a microplate reader at $450 \mathrm{~nm}$ and a $620 \mathrm{~nm}$ reference filter. Each bar represents $\mathrm{M} \pm \mathrm{S}$.D. from three independent experiments. ${ }^{*} p<0.05$ compared with control; HDFs, human dermal fibroblasts; WST-1, water-soluble tetrazolium salt; $M \pm S$.D., mean \pm standard deviation.

(Biopure))을 이용하여 용해시킨 뒤 원심분리하여 상층액을 얻 었다. 얻은 상층액은 $5 \times$ sample buffer $[0.25 \%$ bromophenol blue (Biopure), $0.5 \mathrm{M}$ dithiothreitol (DTT, Invitrogen), $50 \%$ glycerol (Biopure), 0.1\% sodium dodecyl sulfate (SDS; Biopure), 0.25 M Tris-Cl ( $\mathrm{pH}$ 6.8; Biopure)]와 혼합하고 $100{ }^{\circ} \mathrm{C}$ 에서 가열한 뒤 단백질을 추출하였다. 추출된 단백질은 $10 \%$ Tris-HCL SDS gel을 이용해 전기영동하여 크기 별로 분 리한 후, nitrocellulose membrane (Whatman)로 옮겼다. 단백 질이 옮겨진 membrane은 5\% skim milk (Biopure) 용액에 실 온에서 $1 \mathrm{~h}$ 동안 반응시킨 후 anti-JNK, anti-phospho JNK (Cell Signaling Technology, USA) 및 anti- $\beta$ actin (SigmaAldrich) 항체를 $4^{\circ} \mathrm{C}$ 에서 $12 \mathrm{~h}$ 이상 반응시켰다. primary 항 체와 반응시킨 membrane은 0.05\% Tween 20 (Biopure) 가 포함된 $\mathrm{PBS}$ 용액(PBST)으로 수세한 후 $\mathrm{HRP}$-conjugated secondary 항체와 실온에서 $1 \mathrm{~h}$ 반응시켰다. PBST 수세 후, membrane을 enhanced chemiluminescence (ECL; Bio-Rad) 용액과 반응시켜 ChemiDoc ${ }^{\mathrm{TM}}$ Touch Gel Imaging System (Bio-Rad) 기기를 이용하여 membrane상의 단백질 발현양을 확인하였다.

\section{7. 통계분석 방법}

실험 결과값은 세 번의 독립적 실험으로부터 평균값 \pm 표준편 차로 나타내었다. $p<0.05$ 는 Student's t-test를 통해 검증하였 으며 결과값의 유의성을 나타내었다. 


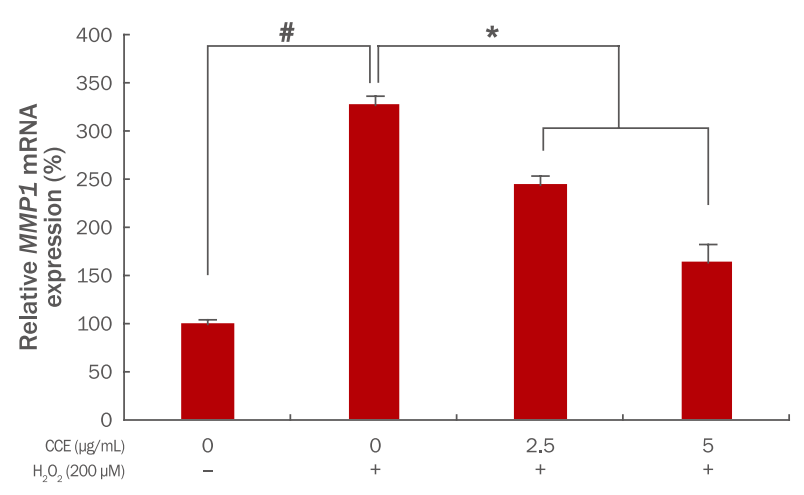

Figure 2. Coptis chinensis extracts inhibit $\mathrm{H}_{2} \mathrm{O}_{2}$-induced $M M P 1$ expression in HDFs.

HDFs were treated with the indicated doses of Coptis chinensis extracts for $9 \mathrm{~h}$, and then with $200 \mu \mathrm{M} \mathrm{H}_{2} \mathrm{O}_{2}$. After further incubation for $24 \mathrm{~h}$, qRT-PCR was performed to evaluate the expression level of $M M P 1$ in HDFs. Values are presented as the $M M P 1$ level normalized to the $\beta$-ACTIN level. Each bar represents $\mathrm{M} \pm$ S.D. from three independent experiments. ${ }^{*} p<0.05$ compared with non-treated cells; " $p<0.05$ compared with $\mathrm{H}_{2} \mathrm{O}_{2}$ treated cells; CCE, Coptis chinensis extracts; MMP1, matrix metalloprotease 1; HDFs, human dermal fibroblasts; qRT-PCR, quantitative real-time polymerase chain reaction; $M \pm S$.D., mean \pm standard deviation.

\section{Results and Discussion}

\section{Coptis chinensis 추출물의 세포독성 평가}

Coptis chinensis 추출물의 세포독성을 평가하기 위해, 배 양된 $\mathrm{HDFs}$ 에 Coptis chinensis 추출물을 $0.5,1,2.5,5,10$ $\mu \mathrm{g} / \mathrm{mL}$ 의 농도로 $24 \mathrm{~h}$ 동안 처리한 뒤 WST-1 assay를 수행 하였다. $5 \mu \mathrm{g} / \mathrm{mL}$ 이하 농도의 Coptis chinensis 추출물이 처리 된 세포에서는 유의적인 세포 생존율의 감소가 관찰되지 않았다 (Figure 1). 그러나 $10 \mu \mathrm{g} / \mathrm{mL}$ 의 Coptis chinensis 추출물이 처 리된 세포에서는 $17 \%$ 이상의 세포 생존율의 감소가 관찰되었다 (Figure 1), 따라서 0.5-5 $\mu \mathrm{g} / \mathrm{mL}$ 농도 대의 Coptis chinensis 추출물은 $\mathrm{HDFs}$ 에서 세포독성이 없는 것으로 확인되며, 이후 실 험에서 $2.5,5 \mu \mathrm{g} / \mathrm{mL}$ 농도의 Coptis chinensis 추출물로 추가 실험을 진행하였다.

\section{Coptis chinensis 추출물의 산화적 스트레스에 의해 증가된 MMP1 mRNA발현 조절 평가}

Coptis chinensis 추출물이 HDFs에서 산화적 스트레스에 의 해 증가된 $M M P 1 \mathrm{mRNA}$ 의 발현을 조절하는지 평가되었다. 피 부세포 내 산화적 스트레스를 유발하는 대표적 활성산소(ROS) 중 하나인 $\mathrm{H}_{2} \mathrm{O}_{2}$ 는 $M M P 1$ 의 발현을 증가시켜 피부노화를 일으 키는 것으로 잘 알려져 있다(Brenneisen et al., 1997). Coptis chinensis 추출물이 ROS에 의해 증가되는 $M M P 1$ 발현을 억제

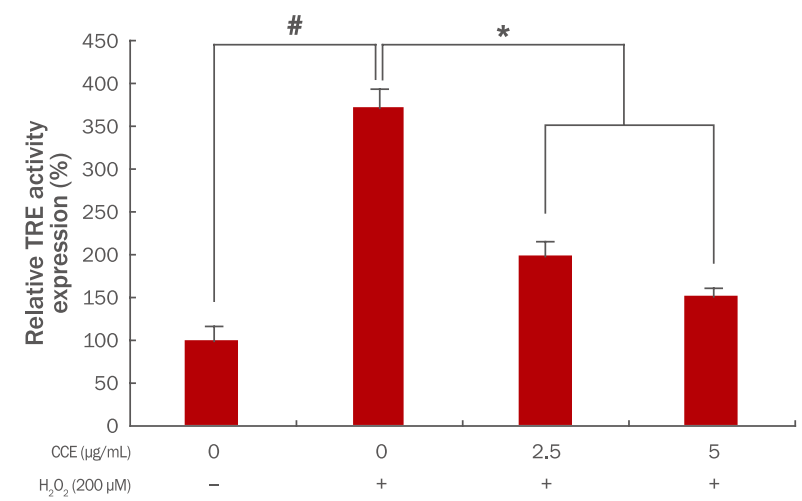

Figure 3. Coptis chinensis extracts repress AP-1 transcriptional activity in HDFs.

The AP-1 (pGL3-TRE) luciferase reporter plasmid was cotransfected with pSV- $\beta$-gal plasmid in HDFs. Cells were treated with the indicated doses of Coptis chinensis extracts for $9 \mathrm{~h}$, and then with $200 \mathrm{MM} \mathrm{H}_{2} \mathrm{O}_{2}$. After further incubation for $24 \mathrm{~h}$, the cells were lysed and luciferase activities in whole cell lysates were measured. Data are the average of three independent experiments with $\mathrm{M} \pm \mathrm{S}$. D.. ${ }^{*} p<0.05$ compared with non-treated cells; * $p<0.05$ compared with $\mathrm{H}_{2} \mathrm{O}_{2}$ treated cells; CCE, Coptis chinensis extracts; AP-1, activator protein-1; HDFs, human dermal fibroblasts; M \pm S.D., mean \pm standard deviation.

할 수 있는 지 평가하고자, HDFs에 Coptis chinensis 추출물 을 전처리 한 후, $200 \mu \mathrm{M}$ 의 $\mathrm{H}_{2} \mathrm{O}_{2}$ 을 처리하여 산화적 스트레스 에 의한 $M M P 1 \mathrm{mRNA}$ 발현 변화를 분석하였다. 우선, $\mathrm{H}_{2} \mathrm{O}_{2}$ 처 리 군에서는 $M M P 1 \mathrm{mRNA}$ 발현이 $\mathrm{H}_{2} \mathrm{O}_{2}$ 을 처리하지 않은 대조 군 대비 $326.24 \%$ 로 증가되었다. Coptis chinensis 추출물 $(2.5$ 및 $5 \mu \mathrm{g} / \mathrm{mL}$ )이 전처리된 세포에서는 $\mathrm{H}_{2} \mathrm{O}_{2}$ 에 의해서 증가되는 $M M P 1$ 발현이 농도의존적으로 감소되는 양상을 나타내었다. 특 히, $2.5 \mu \mathrm{g} / \mathrm{mL}$ Coptis chinensis 추출물이 처리된 세포에서는 MMP1 mRNA 발현이 243.24\%로, $5 \mu \mathrm{g} / \mathrm{mL}$ Coptis chinensis 추출물이 처리된 세포에서는 $163.24 \%$ 로 $M M P 1 \mathrm{mRNA}$ 발현이 $\mathrm{H}_{2} \mathrm{O}_{2}$ 처리 군 대비 감소함을 확인하였다(Figure 2). 이러한 결 과는 Coptis chinensis 추출물이 산화적 스트레스에 의해 증가 된 $M M P 1 \mathrm{mRNA}$ 의 발현을 조절한다는 것을 보여준다.

\section{Coptis chinensis 추출물에 의한 $\mathrm{AP}-1$ 의 전사 활성 평가}

내인성 및 외인성 요인에 의해 생성된 활성산소는 HDFs에 서 mitogen-activated protein (MAPK) cascade (Son et al., 2011)을 통해 MMPs와 같은 collagenase의 발현을 촉진시켜 피 부 내 extracellular matrix $(\mathrm{ECM})$ 의 정상적인 역할을 방해함으 로써 노화를 촉진한다(Fisher \& Voorhees, 1998). 이때 MMPs 유전자의 전사 조절은 $\mathrm{AP}-1$ 에 의해 조절되는데, 활성산소종 에 의한 MAPK 신호전달경로의 활성은 $\mathrm{AP}-1$ 전사 인사의 활성 을 촉진시켜 MMPs의 전사 수준이 상향 조절된다(Kim et al., 
A

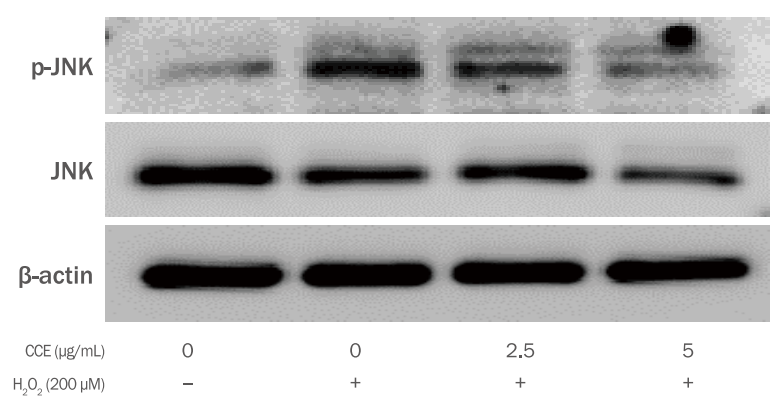

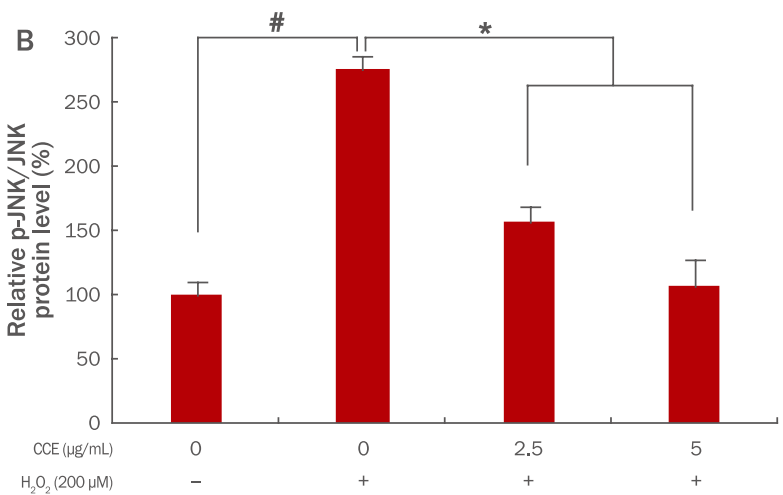

Figure 4. Coptis chinensis extracts suppress JNK phosphorylation and activation in HDFs.

(A) HDFs were treated with the indicated doses of Coptis chinensis extracts for $9 \mathrm{~h}$, and then with $200 \mu_{\mathrm{M} \mathrm{H}} \mathrm{O}_{2}$. After further incubation for $24 \mathrm{~h}$, the cells were lysed and subjected to western blot analysis with anti-JNK or anti-phospho JNK antibodies. (B) Relative quantified expression of $\mathrm{p}$-JNK/JNK. $\beta$-actin used as loading control. Data are the average of three independent experiments with $\mathrm{M} \pm \mathrm{S}$.D.. ${ }^{\#} p<0.05$ compared with non-treated cells; ${ }^{*} p<0.05$ compared with $\mathrm{H}_{2} \mathrm{O}_{2}$ treated cells; CCE, Coptis chinensis extracts; p-JNK, phospho-JNK; JNK,

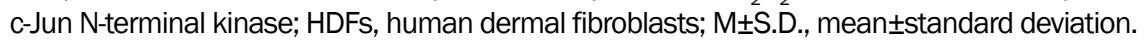

2005; Wenk et al., 1999). 따라서 산화적 스트레스에 의해 유 도된 $\mathrm{HDFs}$ 에 Coptis chinensis 추출물 처리시 관찰된 $M M P 1$ 의 감소가 $\mathrm{AP}-1$ 의 활성과 연관되어 있는지 확인하기 위해 pGL3-TRE luciferase vector가 형질 전환된 HDFs에 Coptis chinensis 추출물을 전처리 한 후, 산화적 스트레스를 유도시켜 세포 내 luciferase 활성을 측정하여, $\mathrm{AP}-1$ 전사활성을 측정하 였다. 먼저 $\mathrm{H}_{2} \mathrm{O}_{2}$ 을 처리한 군에서 산화적 스트레스가 유도되어 $\mathrm{AP}-1$ (TRE promoter)의 활성이 $372.45 \%$ 증가함을 확인하였 다. 같은 조건에서 Coptis chinensis 추출물을 $2.5,5 \mu \mathrm{g} / \mathrm{mL}$ 처리한 군에서는 각각 $199.24 \%$ 및 $152.43 \%$ 로 감소됨을 확인 하였다(Figure 3). 따라서 Coptis chinensis 추출물이 산화적 스트레스에 의해 증가된 $\mathrm{AP}-1$ 의 활성을 감소시켜 $M M P 1$ 의 발 현을 감소시키는 것을 확인하였다.

\section{Coptis chinensis 추출물의 JNK 활성 변화}

피부 세포 내 활성산소는 JNK 단백질의 인산화를 통해 JNK 활성을 촉진한다(Finkel, 2011). 이때 산화적 스트레스에 의해 증가된 $\mathrm{AP}-1$ 의 활성은 분자신호조절자인 $\mathrm{JNK}$ 에 의해 조절된 다(Karin, 1995). 따라서 Coptis chinensis 추출물에 의해 변 화된 $\mathrm{AP}-1$ 활성이 JNK관련 신호전달기전과 연관되어 있는지 확인하기 위해 산화적 스트레스가 유도된 $\mathrm{HDFs}$ 에서JNK 단백 질의 활성을 확인하였다. 먼저 단독으로 $\mathrm{H}_{2} \mathrm{O}_{2}$ 을 처리한 군에서 예상대로 인산화된 JNK 단백질의 발현이 약 2 배 이상 증가함 을 확인하였다. 이와 같은 조건에서 Coptis chinensis 추출물 을 $2.5,5 \mu \mathrm{g} / \mathrm{mL}$ 처리한 군에서는 인산화된 JNK 단백질의 발 현이 농도의존적으로 최대 약 0.8 배 이하로 감소됨을 확인하였 다(Figure 4). 이러한 실험 결과를 통해서 Coptis chinensis 추 출물이 산화적 스트레스에 의해 증가된 $M M P 1$ 의 발현을 $\mathrm{JNK} /$
$\mathrm{AP}-1$ Axis을 억제시킴으로써 세포외기질의 퇴화를 보호하는 효능이 있음을 제시한다.

\section{Conclusion}

Coptis chinensis의 뿌리는 베르베린(berberine)을 포함하 고 있는데 이는 강력한 항균, 항염증, 항암, 지혈, 혈압강하 등 의 약리작용을 가져 주로 약재로써 많이 사용되어 왔다. 또한 강 력한 항산화제로써 간세포 손상 보호와 미백제로써의 기능 등 다양한 작용들이 밝혀지고 있다. 하지만 Coptis chinensis 추 출물에 대한 항노화 작용에 대해서는 아직 정확하게 알려진 것 이 없다. 따라서 본 논문에서 Coptis chinensis 추출물이 산화 적 스트레스가 유도된 인간진피섬유아세포에서 증가된 $M M P 1$ $\mathrm{mRNA}$ 발현을 조절함을 밝혔다. 또한 이러한 결과가 산화적 스 트레스에 의해 증가된 JNK/AP-1 Axis 신호 기전을 억제 시킴 으로써 $M M P 1 \mathrm{mRNA}$ 발현을 억제하는 것을 확인하였다. 따라 서 본 연구결과를 통해 Coptis chinensis 추출물은 외인성 노화 와 내인성 노화에 따른 활성산소에 의한 노화를 억제할 수 있는 새로운 항산화 및 항노화 화장품 물질로써 이용 가능성을 제시 하였다.

\section{Acknowledgements}

이 논문은 해양수산부의 재원으로 해양생명공학기술개발사업 (과제번호: 20150184) 연구개발비 지원에 의해 수행되었습니 다. 


\section{References}

Abergel RP, Chu ML, Bauer EA, Uitto J. Regulation of collagen gene expression in cutaneous diseases with dermal fibrosis: evidence for pretranslational control. The Journal of Investigative Dermatology, 88: 727-731, 1987.

Bergfeld WF. The aging skin. International Journal of Fertility and Women's Medicine, 42: 57-66, 1997.

Birkedal-Hansen H, Moore WG, Bodden MK, Windsor LJ, Birkedal-Hansen B, DeCarlo A, Engler JA. Matrix metalloproteinases: a review. Critical Reviews in Oral Biology and Medicine, 4: 197-250, 1993.

Brenneisen P, Briviba K, Wlaschek M, Wenk J, ScharffetterKochanek K. Hydrogen peroxide $\left(\mathrm{H}_{2} \mathrm{O}_{2}\right)$ increases the steady-state mRNA levels of collagenase/MMP1 in human dermal fibroblasts. Free Radical Biology \& Medicine, 22: 515-524, 1997.

Fisher GJ, Datta SC, Talwar HS, Wang ZQ, Varani J, Kang S, Voorhees JJ. Molecular basis of sun-induced premature skin ageing and retinoid antagonism. Nature, 379: 335339, 1996.

Fisher GJ, Voorhees JJ. Molecular mechanisms of photoaging and its prevention by retinoic acid: ultraviolet irradiation induces MAP kinase signal transduction cascades that induce Ap-1-regulated matrix metalloproteinases that degrade human skin in vivo. Journal of Investigative Dermatology Symposium Proceedings, 3: 61-68, 1998.

Finkel T. Signal transduction by reactive oxygen species. The Journal of Cell Biology, 194: 7-15, 2011

Friedman 0. Changes associated with the aging face. Facial Plastic Surgery Clinics of North America, 13: 371-380, 2005.

Ha MJ, You SH. Bioactive characteristics of extracts of Opuntia humifusa fruit as functional cosmetic ingredients. Asian Journal of Beauty and Cosmetology, 14: 463-472, 2016.

Hattori T, Furuta K, Nagao T, Nagamatsu T, Ito M, Suzuki Y. Studies on the antinephritic effect of plant components (4): reduction of protein excretion by berberine and coptisine in rats with original-type anti-GBM nephritis. The Japanese Journal of Pharmacology, 59: 156-169, 1992.

Karin M. The regulation of AP-1 activity by mitogen-activated protein kinases. The Journal of Biological Chemistry, 270: 16483-16486, 1995.

Kim HH, Shin CM, Park CH, Kim KH, Cho KH, Eun HC, Chung
JH. Eicosapentaenoic acid inhibits UV-induced MMP-1 expression in human dermal fibroblasts. Journal of Lipid Research, 46: 1712-1720, 2005.

Kim YJ. Extracts of Chrysanthemum indicum Linne mediated regulation of MMP1 via JNK-AP1 pathway. Asian Journal of Beauty and Cosmetology, 14: 399-405, 2016.

Lam E, Kilani RT, Li Y, Tredget EE, Ghahary A. Stratifin-induced matrix metalloproteinase- 1 in fibroblast is mediated by c-fos and p38 mitogen-activated protein kinase activation. The Journal of Investigative Dermatology, 125: 230-238, 2005.

Lavker RM. Structural alterations in exposed and unexposed aged skin. The Journal of Investigative Dermatology, 73: 59-66, 1979.

Lavker RM, Veres DA, Irwin CJ, Kaidbey KH. Quantitative assessment of cumulative damage from repetitive exposures to suberythemogenic doses of UVA in human skin. Photochemistry and Photobiology, 62: 348-352, 1995.

Lee DU, Kang YJ, Park MK, Lee YS, Seo HG, Kim TS, Kim $\mathrm{CH}$, Chang KC. Effects of 13-alkyl-substituted berberine alkaloids on the expression of COX-II, TNF-alpha, iNOS and IL-12 production in LPS-stimulated macrophages. Life Science, 73: 1401-1412, 2003.

Lee SY, Kweon TO, Bae JH. Effect of solvent-extracts extracted from Coptis chinensis on seed germination and seeding growth. Protected Horticulture and Plant Factory, 15: 277 282, 2006.

Lee HK, Jeong S, Shin SH, Joo D, Choi SJ, Kim K, An IS, $\mathrm{Kim} \mathrm{KY}, \mathrm{Ku} \mathrm{JE}$, Jeong SH, et al. Coptis chinensis inhibits melanogenesis increasing miR-340-mediated suppression of microphathalmia-associated transcription factor. Biomedical Dermatology, 1: 6, 2017.

Lu J, Guo JH, Tu XL, Zhang C, Zhao M, Zhang QW, Gao FH. Tiron inhibits UVB-induced AP-1 binding sites transcriptional activation on MMP-1 and MMP-3 promoters by MAPK signaling pathway in human dermal fibroblasts. PLoS One, 11: e0159998, 2016.

Mays PK, Bishop JE, Laurent GJ. Age-related changes in the proportion of type I and III collagen. Mechanisms of Ageing and Development, 45: 203-212, 1988.

Ma BX, Meng XS, Tong J, Ge LL, Zhou G, Wang YW. Protective effects of Coptis chinensis inflorescence extract and linarin against carbon tetrachloride-induced damage in 
HepG2 cells through the MAPK/Keap1-Nrf2 pathway. Food and Function, 9: 2353-2361, 2018.

Newberry EP, Willis D, Latifi T, Boudreaux JM, Towler DA. Fibroblast growth factor receptor signaling activates the human interstitial collagenase promoter via the bipartite Ets-AP1 element. Molecular Endocrinology, 11: 11291144, 1997.

Rinnerthaler M, Bischof J, Streubel MK, Trost A, Richter K. Oxidative stress in aging human skin. Biomolecules, 5 : 545-589, 2015.

Smith JG Jr, Davidson EA, Sams WM Jr, Clark RD. Alterations in human dermal connective tissue with age and chronic sun damage. The Journal of Investigative Dermatology, 39: 347-350, 1962.
Son Y, Cheong YK, Kim NH, Chung HT, Kang DG, Pae HO. Mitogen-activated protein kinases and reactive oxygen species: how can ROS activate MAPK pathways? Journal of Signal Transduction, 2011: 792639, 2011.

Sies $\mathrm{H}$, de Groot $\mathrm{H}$. Role of reactive oxygen species in cell toxicity. Toxicology Letters, 64-65: 547-551, 1992.

Wenk J, Brenneisen P, Wlaschek M, Poswig A, Briviba K, Oberley TD, Scharffetter-Kochanek K. Stable overexpression of manganese superoxide dismutase in mitochondria identifies hydrogen peroxide as a major oxidant in the AP-1-mediated induction of matrixdegrading metalloprotease-1. The Journal of Biological Chemistry, 274: 25869-25876, 1999. 


\section{국문초록}

\section{Coptis chinensis 추출물의 JNK/AP1 Axis을 통한 인간진피섬유아세포 내 MMP1}

\section{발현 억제 효능}

김지예 ${ }^{1,2}$, 배승희 ${ }^{1}$, 정진혁 ${ }^{2}$ 안성관 ${ }^{1}$, 안인숙 ${ }^{2}$, 김영삼 $^{3 *}$

${ }^{1}$ 건국대학교 화장품공학과 질병분자표적신약연구소, 서울, 한국

2한국피부과학연구원, 서울, 한국

${ }^{3}$ 건국대학교 산업대학원 이미지산업학과, 서울, 한국

목적: Coptis chinensis 추출물은 강력한 항균, 항염증, 항암, 지혈, 혈압강하 등의 약리작용을 가져 주로 중국의 전통 약재로써 많 이 사용되어 왔다. 하지만 Coptis chinensis 추출물에 대한 항노화 작용에 대해서는 아직 정확하게 알려진 것이 없다. 따라서 본 연구에서는 Coptis chinensis 추출물의 matrix metalloprotease 1 (MMP1) 발현 조절에 대한 분자세포학적 기전을 밝히고 나아 가 새로운 항노화 화장품 원료로써의 가능성을 밝히고자 한다. 방법: Coptis chinensis 추출물의 산화적 스트레스에 의해 증가 된 $M M P 1$ 발현 억제 효능을 평가하기 위해 인간진피섬유아세포를 사용하였다. 먼저, 추출물에 대한 세포독성평가를 위해 watersoluble tetrazolium salt (WST-1) assay방법으로 세포생존율에 영향을 미치지 않는 농도를 선별하였다. $\mathrm{H}_{2} \mathrm{O}_{2}(200 \mu \mathrm{M})$ 가 처리된 인간진피섬유아세포에 Coptis chinensis 추출물을 선별된 농도로 처리한 후 $M M P 1 \mathrm{mRNA}$ 의 발현 변화를 quantitative real-time polymerase chain reaction (qRT-PCR)로 분석하였다. 또한 luciferase reporter assay을 통해 추출물에 의한 $M M P 1 \mathrm{mRNA}$ 의 발 현 변화가 AP-1 전사 활성과 관련되어 있는지 분석하였다. 마지막으로 c-Jun N-terminal kinase (JNK) 단백질 활성을 평가하 기 위해 JNK와 phospho-JNK의 단백질 발현을 western blot 분석방법을 통해 확인하였다. 결과: Coptis chinensis 추출물의 인간 진피섬유아세포에 대한 세포독성은 $5 \mu \mathrm{g} / \mathrm{mL}$ 이하 농도에서 관찰되지 않았다. 세포독성이 관찰되지 않은 농도의 Coptis chinensis 추출물은 인간진피섬유아세포에서 산화적 스트레스에 의해 증가된 $M M P 1 \mathrm{mRNA}$ 의 발현을 억제함을 확인하였다. 이러한 Coptis chinensis 추출물의 효과는 산화적 스트레스에 의해 증가된 JNK/AP-1 Axis 신호 기전을 억제시킴으로써 $M M P 1$ 의 발현을 조절함 을 밝혔다. 본 연구결과는 Coptis chinensis 추출물은 JAK/AP-1 Axis 신호 기전을 통해 $M M P 1$ 의 발현을 조절한다는 것을 보여준 다. 결론: 본 논문의 연구결과는 Coptis chinensis 추출물의 외인성 노화와 내인성 노화에 따른 노화에 대한 항산화 및 항노화 효과 를 보여주면서 새로운 기능성 화장품 소재로써의 이용 가능성을 제시한다.

핵심어: Coptis chinensis, 진피섬유아세포, 기질금속단백질분해효소, 산화적 스트레스, JNK/AP-1

이 논문은 해양수산부의 재원으로 해양생명공학기술개발사업(과제번호: 20150184) 연구개발비 지원에 의해 수행되었습니다.

\section{참고문헌}

김영주. JNK-AP1 기전을 통한 국화꽃 추출물의 $M M P 1$ 발현 변화 조절. 아시안뷰티화장품학술지, 14: 399-405, 2016. 이승엽, 권태오, 배종향. 종자발아 및 유묘생장에 미치는 황련(Coptis chinessis) 추출물의 영향. 시설원예·식물공장, 15: 277-282, 2006.

하민정, 유선희. 천년초 열매 추출물의 기능성 화장품 소재로서의 생리활성 특성. 아시안뷰티화장품학술지, $14: 463-$ 472, 2016. 


\section{中文摘要}

\section{黄连提取物通过JNK/AP-1轴抑制人皮肤成纤维细胞内MMP1表达的功效}

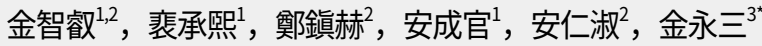

建国大学化妆品工学科疾病分子靶标新药研究所, 首尔, 韩国

2韩国皮肤科学研究院, 首尔, 韩国

3建国大学产业大学院影像产业学科, 首尔, 韩国

目的: 黄连提取物具有很强的抗菌, 抗炎, 抗癌, 止血和降血压作用, 已被广泛用作中药产品。然而, 黄连提 取物的抗衰老作用尚不清楚。因此, 本研究旨在阐明黄连提取物对 $M M P 1$ 表达的分子机制, 探讨这些药物作 为新型抗衰老化妆品成分的可能性。方法: 人真皮成纤维细胞用于评价黄连提取物对氧化应激诱导的matrix metalloprotease 1 (MMP1) 表达的抑制作用。首先, 为了评估提取物的细胞毒性, 通过water-soluble tetrazolium salt (WST-1) 方法, 选择不影响细胞存活率的浓度。在用 $\mathrm{H}_{2} \mathrm{O}_{2}(200 \mu \mathrm{M})$ 处理的人皮肤成纤维 细胞中, 用选定浓度的黄连提取物处理后, 通过quantitative real-time polymerase chain reaction (qRTPCR）分析MMP1 mRNA的表达。此外, 通过luciferase reporter assay测定提取物对MMP1 mRNA的表达 与activator protein-1 (AP-1) 转录活性的相关关系。最后, 通过western blot分析评估c-Jun N-terminal kinase（JNK）和磷酸化JNK的蛋白质表达以评估JNK蛋白质活性。结果: 在浓度低于 $5 \mu \mathrm{g} / \mathrm{mL}$ 时, 未观察到黄 连提取物对人皮肤成纤维细胞的细胞毒性。发现, 无细胞毒性的黄连提取物预处理的细胞显示抑制氧化应激诱 导的MMP1 mRNA的下调。进一步实验表明，这些黄连提取物通过抑制JNK/AP-1轴信号传导机制来调节MMP1 的表达。以上结果表明, 黄连提取物通过JAK/AP-1轴信号传导途径来调节MMP1表达。结论: 本研究结果表 明, 黄连提取物对外源衰老和内源性衰老引起的衰老具有抗氧化和抗衰老作用。因此, 作为新型功能性化妆品 成分充分具有可行性。

关键词：黄连，人皮肤成纤维细胞，基质金属蛋白酶，氧化应激，JNK/AP-1 
